\title{
CRIMINAL ACTIVITIES AND THE SPREAD OF COVID 19 IN NIGERIA
}

\author{
Nkwocha, Daniel Ibeawuchi \\ $\mathrm{PhD}$, Department of Sociology, \\ Imo State University, Owerri \\ Imo State, Nigeria
}

\begin{abstract}
This work investigated the criminal activities of the Nigerian security operatives and the spread of covid 19. The objective of this research examined whether the lackadaisical attitude of the Nigerian security operatives contributed to the spread of the Corona Virus in Nigeria. The researcher formulated one hypothesis which states that there is a significant relationship between the lackadaisical attitude of the Nigerian security operatives and the spread of corona virus in Nigeria. 328 set of questionnaire were distributed while the researcher retrieved only 326 questionnaire. The questionnaire served as a source of primary data, while library research was source of secondary data. We adopted the survey research design for this study. The purposive sampling technique was adopted. Our hypothesis was tested using the chisquare statistical tool. We found out that women involvement in management positions has contributed greatly in ensuring that they effectively care for their children. This is not in line with Taiwo (2015) that most women who find themselves as managers in organizations tend to have little or no attention for their children. But the it is in line with item 1 in table II as $\mathbf{5 5 . 5}$ percent of the respondents strongly agreed that women's involvement in management positions has enabled them (women) effectively care for their children. Based on the research findings, we recommend that: More women should be granted the opportunity to be involved in managerial positions in their various organizations so that they would be able to care for their children and other family members.
\end{abstract}

Keywords - Corona virus, Criminal activities, Crime, Disease, Border, Security operatives.

\section{INTRODUCTION}

Corona virus also known as Covid 19 is a deadly virus that took the world by surprise towards the end of 2019. This deadly virus started from China and later started spreading into other countries including Nigeria. The first confirm case in Nigeria was announced on 27 February, 2020 when an Italian citizen in Lagos tested positive for the virus. On 9 March, 2020 a second case of the virus was reported in Ogun state, ewekoro precisely, from a Nigerian who came in contact with the Italian. With time, the virus started spreading into other parts of the country. Early March, the minister of health in Nigeria, Osagie Ehanire, announced that 60 persons who had contact with the index Italian patient were under isolation, 40 persons in Ogun State and 20 in Lagos State. On 1 March, four Chinese citizens were quarantined in Plateau State, they all tested negative the following day. On 3 March, the governor of Lagos State, Babajide Sanwo-Olu disclosed that two foreign Nationals from an unnamed Asian country has tested negative to the virus. On 6 March, the Anambra State government announced that five Chinese citizens tested negative for the virus. The Nigeria Centre for Disease Control reported that a total of 219 primary and secondary contacts of the index case had been identified and were being actively monitored. On 9 March, the President Muhammadu Buhari established a Presidential Task Force for the control of the virus in the country. On 10 March, Turkish Airlines cancelled all their flights to Nigeria due to the virus outbreak. On 15 March, a woman in Enugu State displayed the symptoms of coronavirus, she tested negative the following day. On 17 March, Nigeria postponed the 20th national sports festival that was supposed to hold in Benin City, Edo State from 22 March to 1 April. On 18 March, the management of the National Youth Service Corps suspended the 2020 Batch A stream one 21 days orientation exercise indefinitely. The orientation exercise commenced on 10 March and was expected to end on 30 March, before it was suspended after just 8 days. Later the same day, Nigeria placed a travel ban on 13 countries with high cases of the virus, the countries are; United States, United Kingdom, South Korea, Switzerland, Germany, France, Italy, China, Spain, Netherlands, Norway, Japan and Iran. In Katsina State, a Nigerian citizen that returned from displayed the symptoms of the virus, he tested negative the following day. Kano State government confirmed that three persons tested negative for the virus in the state. Lagos State government banned religious gatherings of over 50 worshippers for 30 days, Ogun State also banned any gathering of more than 50 people for 30 days. The New Afrika Shrine suspended all their programmes indefinitely. Kwara State and Lagos State announced the indefinite closure of their public and private schools, while Zamfara State, Sokoto State, Katsina State, Niger State, Kano State, Jigawa State, Kebbi State and Kaduna State also closed down their schools for 30 days from 23 March. The Nigeria Football Federation suspended all 


\section{International Journal of Engineering Applied Sciences and Technology, 2020 Vol. 5, Issue 4, ISSN No. 2455-2143, Pages 626-630 \\ Published Online August 2020 in IJEAST (http://www.ijeast.com)}

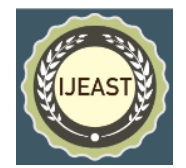

football activities for four weeks. On 19 March, Anambra State government announced the closure of their schools and suspension of public gatherings indefinitely, tertiary institutions to close from 20 March, while primary and secondary schools to close from 27 March. Ogun State government extended an earlier ban to schools and religious centres in the state indefinitely. Federal government announced the closure of tertiary institutions, secondary and primary schools. Enugu State government also ordered the closure of all primary and secondary schools in the state from 27 March. On 20 March, Nigeria extended their travel ban to two more countries, Sweden and Austria. Imo State government banned social, political, religious and family gatherings of more than 20 persons. The state also ordered the closure of all their schools from 23 March. Nigeria announced the closure of their international airports, Enugu, Port Harcourt and Kano airports from 21 March. Rivers State government also announced the closure of all their schools and directed the restriction of all religious activities. Osun State government banned any public gatherings of more than 50 persons in the state with immediate effect, including schools, churches and mosques. Delta State government announced the closure of all their schools from 26 March. During this periods, the Nigerian government deployed security personnel to mount the roads and borders of the Federal republic of Nigeria which made Nigerians to obey the lock down rules. Even when the federal government deployed security personnel to ensure that no one comes into the country either through road, sea or air, it seems the security officers compromised by collecting bribes from both foreigners and citizens of Nigeria in order to enable them enter into the country without proper check, which seems to have led to high increase of the virus in Nigeria. Also, it seems that some of the security operatives were not serious with the tasks the federal government gave to them, some of them abandoned their duty post which made the country more vulnerable to spread of the deadly Corona Virus. Therefore, this work examined the lackadaisical attitude of the Nigerian security operatives in the spread of the deadly Covid 19 virus in Nigeria.

\section{OBJECTIVE OF THE STUDY}

To examine whether the lackadaisical attitude of the Nigerian security operatives contributed to the spread of the Corona Virus in Nigeria.

\section{HYPOTHESIS}

There is a significant relationship between the lackadaisical attitude of the Nigerian security operatives and the spread of Covid 19 in Nigeria.

\section{LITERATURE REVIEW AND THEORETICAL FRAMEWORK}

Oriaku (2020) asserts that participation of the Nigerian security operatives in ensuring that Corona virus does not spread faster into Nigeria is only but a show of shame. For him, instead of the security men to face what the government instructed them to do, they were busy extorting motorists and other. Ikenna and Uwadi (2020) argues that the Nigerian security men turned the assignment into a money making machine business which eventually gave the virus full access into the country. Hedges (2020), posited that the Nigerian police force and other paramilitary agencies needs total reformation and that unless this is done, corruption will continue to swim smoothly in Nigeria. In its report about Nigeria's coronavirus lockdown period, the NHRC, a government agency, said it had found "8 separate incidents of extrajudicial killings leading to 18 deaths". In total the group said it received more than 100 complaints across 24 of Nigeria's 36 states - including Lagos, Ogun and Abuja. Those three parts of the country this week had their two-week lock down extended. Other areas have set a variety of restrictions, which have seen the police and army called out to enforce them. Nigerian security forces have not responded to the NHRC's report.But earlier this month, Nigeria's police force encouraged citizens to report officers who violate rules on conduct adding "the rights of Nigerians are not infringed upon under any pretext". Despite all the allegations of bribe leveled against the Nigerian security operatives, non of its top personnel has really spoken to the press about it (Sadiq, 2020). This is why Ndu (2019) asserted that significant relationship exists between the Nigerian police force and corruption. The government of Nigeria has taken a variety of measures to control the spread of the novel corona virus, including restrictions on movement that are being enforced by law enforcement agencies and the military. Although inter-agency cooperation between the police and other institutions has increased as a result, enforcement of the lock-down has also amplified existing challenges around human rights abuses and bureaucratic corruption within these state institutions (Benson, 2020). The police and the military have also been accused of profiteering from the lockdown by taking bribes from motorists in exchange for free passage at check points. Amidst the pandemic, organised crime has actually been on the rise. The Nigerian National Drug Law Enforcement Agency is still arresting drug traffickers who have continued operations despite the lockdown. Security agents who have turned checkpoints into cash cows provides some clue as to how this happened. Cybercrime has also increased through the sale of fake medical products online (Bexil, 2020).

COVID-19 is bringing a fact to our doorstep: Citizens should be able to easily report misconduct by officials from the comfort of their homes. It is essential for all institutions in Nigeria, especially in the corruption-prone areas of law enforcement and security, to take lessons from the police force's CRU and establish channels that enable citizens to report their grievances (Eze, 2020). Henry (2020) stated that 
countless ordinary Nigerians attempting to make precarious ends meet as taxi drivers, market traders, and shopkeepers are accosted on a daily basis by armed police officers who demand bribes and commit human rights abuses against them as a means of extorting money even in this period of Covid 19. Those who fail to pay are frequently threatened with arrest and physical harm. Far too often these threats are carried out. Meanwhile, victims of crime are obliged to pay the police from the moment they enter a police station to file a complaint until the day their case is brought before a court (Ikenna, 2020). In the view of Jacob (2020), high-level police officials embezzle staggering sums of public funds meant to cover basic police operations. Senior police officers also enforce a perverse system of "returns" in which rank-and-file officers are compelled to pay up the chain of command a share of the money they extort from the public. Mumuni (2020) stated that those charged with police oversight, discipline, and reform have for years failed to take effective action, thereby reinforcing impunity for police officers of all ranks who regularly perpetrate crimes against the citizens they are mandated to protect. Extortion, embezzlement, and other corrupt practices by Nigeria's police undermine the fundamental human rights of Nigerians in two key ways. First, the most direct effect of police corruption on ordinary citizens stems from the myriad human rights abuses committed by police officers in the process of extorting money. These abuses range from arbitrary arrest and unlawful detention to threats and acts of violence, including physical and sexual assault, torture, and even extrajudicial killings (Nonso, 2017). During this period of covid 19, the police frequently extort money from the public at taxi stands, in marketplaces, or while going about their daily lives (Olopade, 2020). However, the most common venue for extortion occurs at police roadblocks, ostensibly put in place to combat crime. In practice, these checkpoints have become a lucrative criminal venture for the police who routinely demand bribes from drivers and passengers alike, in some places enforcing a de facto standardized toll (Paul, 2020).

\section{METHODOLOGY}

The research design for this work is the survey research design. Survey research design means the investigation of the opinion, behaviour or other manifestations of a group by questioning them. The researcher adopted the survey research design because of its flexibility to permit the use of a variety of data collection techniques. Also, survey research design sensitizes the researchers to potential problems that were originally unknown. The area of this study is the 3 senatorial zones in Imo State, Nigeria. The researcher purposively chose a sample of 435 respondents. The researchers adopted the purposive sampling technique because of the nature of the topic under study. The researcher used the questionnaire to gather data for the study, the researcher also used secondary methods such as text books, journals, etc. Data obtained was presented using simple percentages and tables, while the hypothesis was tested using the chi-square $\left(\mathrm{X}^{2}\right)$ statistical tool. This is because it enhances calculation and comprehension. It also gives the opportunity to establish relationship between variables.

Formular for chi-square (X2)

$\begin{array}{lll}\frac{\sum(\mathrm{O}-\mathrm{E})}{\mathrm{E}} & \\ \mathrm{O}= & \text { Observed frequency } \\ \mathrm{E} \quad= & \text { Expected frequency } \\ \Sigma & = & \text { Summing over the cells. }\end{array}$

\section{RESULT AND DISCUSSION}

Table II Nigerian Security Operatives and Spread of Covid 19

\begin{tabular}{|c|c|c|c|c|c|c|c|}
\hline & Questions & SA & $\mathrm{A}$ & $\mathrm{SD}$ & $\mathrm{D}$ & $\begin{array}{l}\text { Tot } \\
\text { al } \\
\text { sa } \\
\text { mpl } \\
\text { e }\end{array}$ & $\%$ \\
\hline 1 & $\begin{array}{lr}\text { Police } & \text { officers } \\
\text { were } & \text { busy } \\
\text { extorting } & \text { people } \\
\text { during covid } 19 & \\
\text { lock down } & \end{array}$ & $\begin{array}{l}181 \\
(55.5 \\
\%)\end{array}$ & $\begin{array}{l}101 \\
(31 \\
\%)\end{array}$ & $\begin{array}{l}19 \\
(5.8 \\
\%)\end{array}$ & $\begin{array}{l}25 \\
(7.7 \\
\%)\end{array}$ & 326 & $\begin{array}{l}10 \\
0\end{array}$ \\
\hline 2 & $\begin{array}{l}\text { The Nigerian } \\
\text { security forces } \\
\text { were responsible } \\
\text { for more deaths } \\
\text { than the virus }\end{array}$ & $\begin{array}{l}171 \\
(52.4 \\
\%)\end{array}$ & $\begin{array}{l}152 \\
(46 . \\
6 \%)\end{array}$ & $\begin{array}{l}15 \\
(4.6 \\
\%)\end{array}$ & $\begin{array}{l}22 \\
(6.7 \\
\%)\end{array}$ & 326 & $\begin{array}{l}10 \\
0\end{array}$ \\
\hline 3 & $\begin{array}{l}\text { Due to the } \\
\text { lackadaisical } \\
\text { attitude of the } \\
\text { security personnel } \\
\text { in Nigeria, the } \\
\text { virus easily spread } \\
\text { into other parts of } \\
\text { the country that } \\
\text { had few or zero } \\
\text { cases }\end{array}$ & $\begin{array}{l}20 \\
(6.1 \\
\%)\end{array}$ & $\begin{array}{l}14 \\
(4.3 \\
\%)\end{array}$ & $\begin{array}{l}168 \\
(51 . \\
5 \% \\
)\end{array}$ & $\begin{array}{l}158 \\
(48 . \\
5 \%)\end{array}$ & 326 & $\begin{array}{l}10 \\
0\end{array}$ \\
\hline 4 & $\begin{array}{l}\text { The Nigerian } \\
\text { security operatives } \\
\text { gave in their best } \\
\text { to ensure that the } \\
\text { virus didn't spread } \\
\text { into other parts of } \\
\text { the country }\end{array}$ & $\begin{array}{l}7 \\
(2.1 \\
\%)\end{array}$ & $\begin{array}{l}21 \\
(6.4 \\
\%)\end{array}$ & $\begin{array}{l}110 \\
(33 . \\
7 \% \\
)\end{array}$ & $\begin{array}{l}188 \\
(57 . \\
7 \%)\end{array}$ & 326 & $\begin{array}{l}10 \\
0\end{array}$ \\
\hline 5 & $\begin{array}{l}\text { The Nigerian } \\
\text { security personnel } \\
\text { extorted members } \\
\text { of the public } \\
\text { during the Covid } \\
19 \text { pandemic } \\
\begin{array}{l}\text { because the } \\
\text { government is not } \\
\text { paying them }\end{array}\end{array}$ & $\begin{array}{l}111 \\
(34.0 \\
\%)\end{array}$ & $\begin{array}{l}187 \\
(57 . \\
4 \%)\end{array}$ & $\begin{array}{l}25 \\
(7.7 \\
\%)\end{array}$ & $\begin{array}{l}3 \\
(0.9 \\
\%)\end{array}$ & 326 & $\begin{array}{l}10 \\
0\end{array}$ \\
\hline
\end{tabular}


The above table shows that 55.5 percent of the respondents affirmed that the security operatives in Nigeria were busy extorting money from members of the public during the covid 19 lockdown in the country. This could one of the reasons why the virus spread so fast into other parts of the country with little or zero cases.

Table III Chi-Square Analysis for Nigerian Security Operatives and Spread of Covid 19.

\begin{tabular}{|l|l|l|l|l|l|}
\hline Items & SA & $\mathrm{A}$ & $\mathrm{D}$ & SD & Total \\
\hline 1 & 181 & 101 & 19 & 25 & $326 \mathrm{~B} 1$ \\
\hline 3 & 20 & 14 & 168 & 158 & $326 \mathrm{~B} 2$ \\
\hline 4 & 7 & 21 & 110 & 188 & $326 \mathrm{~B} 3$ \\
\hline Total & 208A1 & $136 \mathrm{~A} 2$ & $297 \mathrm{~A} 3$ & $371 \mathrm{~A} 4$ & 978 \\
\hline
\end{tabular}

Computing formular for chi-square

$\mathrm{X} 2=\sum\left(\mathrm{O}_{1}-\mathrm{E}_{1}\right)^{2}$

Where $\sum=$ Summation

$$
\mathrm{O}=\text { Observed values }
$$

$\mathrm{E}=$ Expected values

To obtain the expected frequencies

$\mathrm{E}=\underline{\text { Row total } \mathrm{x} \text { column }}$

Grand total

Placing the observed and expected values in a tabular form, we have;

Table 4.2.2: Data for Nigerian Security Operatives and Spread of Covid 19

\begin{tabular}{|l|l|l|l|}
\hline & $E$ & $(\mathrm{O}-\mathrm{E})$ & $(\mathrm{O}-\mathrm{E})^{2 / \mathrm{E}}$ \\
\hline 208 & 69.3 & 138.7 & 4.0 \\
\hline 136 & 45.3 & 90.7 & 4.0 \\
\hline 297 & 99 & 236.7 & 4.7 \\
\hline 371 & 123.7 & 247.3 & 3.8 \\
\hline 208 & 69.3 & 138.7 & 4.0 \\
\hline 136 & 45.3 & 90.7 & 4.0 \\
\hline 297 & 99 & 198 & 4 \\
\hline 371 & 123.7 & 247.3 & 3.9 \\
\hline 208 & 69.3 & 138.7 & 4.0 \\
\hline 136 & 45.3 & 90.7 & 4 \\
\hline 279 & 99 & 180 & 3.6 \\
\hline 371 & 123.7 & 247.3 & 3.9 \\
\hline
\end{tabular}

The table above is a $4 \times 2$ contingency table, hence the degree of freedom.

$(\mathrm{df})=(\mathrm{C}-1)(\mathrm{R}-1)$

$(\mathrm{df})=(4-1)(2-1)$

$\mathrm{df}=3 \times 1=3$

Thus, $\mathrm{df}=3$.

The table value of $X^{2}$ at a significance level of 0.05 and degree of $3=7.815$. The calculated value of $x^{2}=47.9$. Since the calculated value of $X^{2}$ is greater than the table value of $X^{2}$, we therefore accept the alternate hypothesis which states that there is a significant relationship between the Nigerian security operatives and spread of covid 19.

\section{Discussion of findings}

From the study carried out on criminal activities and the spread of covid 19 in Nigeria, we found that: relationship exists between the lackadaisical attitude of the Nigerian security operatives and the spread of Covid 19 in Nigeria. This is in line with Oriaku (2020) that participation of the Nigerian security operatives in ensuring that Corona virus does not spread faster into Nigeria is only but a show of shame. For him, instead of the security men to face what the government instructed them to do, they were busy extorting motorists and others.

\section{CONCLUSION}

Base on the research carried out on criminal activities and the spread of covid 19 in Nigeria, the reseacher conclude that the security operatives in Nigeria are not doing their work the way they out to, thereby putting the country into grave danger especially in this period of covid 19.

\section{RECOMMENDATION}

Based on the findings, we recommend that the Nigrian police and other security agencies in Nigeria should undergo serious restructuring. The government should also consider increasing their salary so that they would be able to carry out their duties without extorting innocent and defenseless citizens especially in a season of serious pandemic such as the Covid 19.

\section{REFERENCE}

[1] Benson, A. J. (2020) Corona Virus Pandemic and the Security Forces in Nigeria. Journal of interdisciplinary studies 4(4) (pp. 15-20).

[2] Bexil, C. (2020)The role Security men in curbing the spread of the Corona virus in Africa. Bombay: Bombay academic press limited. (pp 43-49).

[3] Elis O .(2020). Emergent and Recurrent Issues Affecting the Nigeria Military and Para Military4(2). (pp.39-45). 
[4] Eze W. (2020). The participation of Armed men in the fight against Corona Virus. New York: Social Problem academic Press.(pp. 78-87)

[5] Henry M.(2020). Corruption in the Nigerian police force. Lagos: Nwokedi Publishers. (pp.35 -42).

[6] Ikenna I (2020).Corruption in the Nigerian armed forces. 12(11) (pp.12-20).

[7] Jacobs, (2020). Nigeria police force Vs the public. (pp.4349).

[8] Maduba R. (2020). Structure of the Nigerian Paramilitary. Journal of Crime and criminology. 15(15) (pp.281-301).

[9] Mumuni M.(2020). Covid19 pandemic and corruption in Nigeria. 13(16) (pp.11-14)

[10] Nonso R.(2017) Extortion and other corrupt practices by the Nigerian police. Lagos: Ewekoro publishers. (pp.1317)

[11] Olopade O. (2020)The Nigerian Police and Reformation. Abeokuta: Babalola publishers. (pp.15-18).

[12] Paul R.(2020). The Nigerian state and the spread of covid 19. Lagos: Ogunmola Publishers. (pp23-24)

\section{ACKNOWLEDGEMENTS}

The researcher is so greatful to his research assistant for his unreserved assistance during the course of this work. The researcher also acknowledge all the authors that their works were cited in this research. 